\title{
An Updated Checklist of Benthic Polychaetes of Asia's Largest Brackish Water Coastal Lagoon -The Chilika Lake
}

Mahapatro $\mathrm{D}^{1 *}$, Panigrahy $\mathrm{RC}^{1}$, Panda $\mathrm{S}^{2}$ and Mishra $\mathbf{R K}^{3}$

${ }^{1}$ Department of Marine Sciences, Berhampur University, Berhampur, Ganjam, Odisha, India

${ }^{2}$ Department of Forest and Environment, Bhubaneswar, Odisha, India

${ }^{3}$ National Centre for Antarctic and Ocean Research (NCAOR), MoES, Goa- 403 804, India

\begin{abstract}
Present study was carried out during the year 2007 to 2010, to describe the polychaete species in the Chilika lake after opening of a new lagoon inlet. A total of 45 polychaete species from the lake was observed. Among the dominant species Nereis reducta, Capitella capitata, Heteromastus filliformis, Minuspio cirrifera were conspicuous. Similarly, the taxa recorded first time in the lake were Amphictene auricoma, Spiophanes bombyx, Mediomastus, Pomatoceros caeruleus, Hydroides elegans, Pisione remota, Hesione picta, Eteone picta, Eumida sanguine, Bipalponephtys cornuta. These species were typical marine forms. This might be possible due to the opening of a new lagoon inlet. However, few indicator species like Capitella sp., and Minuspio sp. were observed from northern sector. From the entire study it was evidenced that sandy substratum of outer channel area appeared as the most suitable habitat for proliferation of benthic polychaete taxa.
\end{abstract}

Keywords: Benthic polychaetes; Outer channel area; Chilika lake

\section{Introduction}

During the recent periods, coastal ecosystems are much influenced by the natural and anthropogenic stresses. Some of the major stressors include sedimentation, eutrophication, heavy floods, tropical cyclones etc. These natural events can put moderate to severe impact upon macrobenthic community assemblage by altering the bottom sediment significantly $[1,2]$. This phenomenon is mostly seen in the shallow coastal ecosystems of tropical region $[1,2]$. The macrobenthos of tropical region is mostly dominant by polychaete $[1,3]$. Benthic polychaetes, because of the high level of adaptation, exhibited ubiquitous distribution in coastal and marine ecosystem. Certain features of polychaetes like limited mobility and ability to withstand in polluted conditions are tremendously helpful to the scientific community. Thus it has got virtual attention of different researchers and scientists worldwide, since they use it in eco-toxicological studies [4,5]. It is observed that under polluted conditions, the number of polychaetes may be high or low or complete impoverishment of taxa might be possible. But a higher level of species richness or diversity value of benthic polychaete may indicate a healthy condition of the ecosystem [6,7]. Besides this, it possess immense ecological functioning such as: (i) it is actively involved in the bio-geo-chemical cycling process $[5,8,9]$, (ii) it acts as a coupling structure between meiofauna and macrofauna community in marine sediment [3], (iii) provides substantial contribution to the demershal fisheries of the tropical region [10], (iv) it interlinks the benthic community to the higher level trophic strata in the marine food chain [11].

Perusal of literatures revealed that, research on diversity and distribution of benthic polychaete on different coastal ecosystems of India has got maximum attention [3,12-21]. Although, research on benthic polychaetes in India was started from Chilika lake [22]. But recent study on this aspect was less. However, the lake is one of the most important ecosystems in the world enriched with biodiversity and vast destination for exploitable fishery resource. During the last couple of decades, the lake had faced many of the changes derived from natural and anthropogenic sources. Because of such events the lagoon inlet was closed. To revive the lake ecosystem from degradation a new mouth was dredged during the year 2000. Then, after couple of years the lagoon had regained its pristine condition. Though, benthic polychaete is used as the indicator of environmental stress. But, in the context of Chilika lake very less information is available so far [20]. Thus, the present study was planned (i) to prepare a complete checklist of benthic polychaetes, (ii) to compare the present set of information with previously data set and (iii) to find out the occurrence of any pollution indicator species.

\section{Materials and Methods}

\section{Study area-The Chilika Lake}

Chilika lake is also called as a brackish water coastal lagoon. It is a shallow pear shaped ecosystem, provides enormous habitat support to a variety of flora and fauna. It appeared as an important destination for migratory birds and tourists. It is located between latitude $19^{\circ} 28^{\prime}$ and $19^{\circ} 54^{\prime}$ and longitude $85^{\circ} 05^{\prime}$ and $85^{\circ} 38^{\prime}$ of east coast of India adjoining to Bay of Bengal (Figure 1). The length of the lake is $64 \mathrm{~km}$ and width is varied from 2 to $20 \mathrm{~km}$ respectively. In summer the lake area shrink to $906 \mathrm{sq} \mathrm{km}$ from $1156 \mathrm{sq} \mathrm{km}$ in monsoon. It provides the socio-economic support to a population of 0.2 million residing in and around of it. They are mostly depended on fisheries and tourism sector. Every year almost a million of migratory birds often find their destination to Chilika lake. Mostly to the Nalabana bird Is. and Mangalajodi. It has vast exploitable fishery resource and thus provides immense socioeconomic support. Due to which the name of Chilika lake is included in the Ramsar site in 1981. Four ecological subdivisions were considered in the lake on the basis of salinity and composition of flora and fauna such as northern

${ }^{*}$ Corresponding author: Dr. Debasish Mahapatro, Department of Marine Sciences, Berhampur University, Berhampur-760007, Ganjam, Odisha, India, Tel: 9438237102; E-mail: dsmahapatro@gmail.com

Received April 03, 2015; Accepted May 20, 2015; Published June 02, 2015

Citation: Mahapatro D, Panigrahy RC, Panda S, Mishra RK (2015) An Updated Checklist of Benthic Polychaetes of Asia's Largest Brackish Water Coastal Lagoon -The Chilika Lake. J Coast Zone Manag 18: 406. doi: 10.4172/2473-3350.1000406

Copyright: (c) 2015 Mahapatro D, et al. This is an open-access article distributed under the terms of the Creative Commons Attribution License, which permits unrestricted use, distribution, and reproduction in any medium, provided the original author and source are credited. 
Citation: Mahapatro D, Panigrahy RC, Panda S, Mishra RK (2015) An Updated Checklist of Benthic Polychaetes of Asia's Largest Brackish Water Coastal Lagoon -The Chilika Lake. J Coast Zone Manag 18: 406. doi: 10.4172/2473-3350.1000406

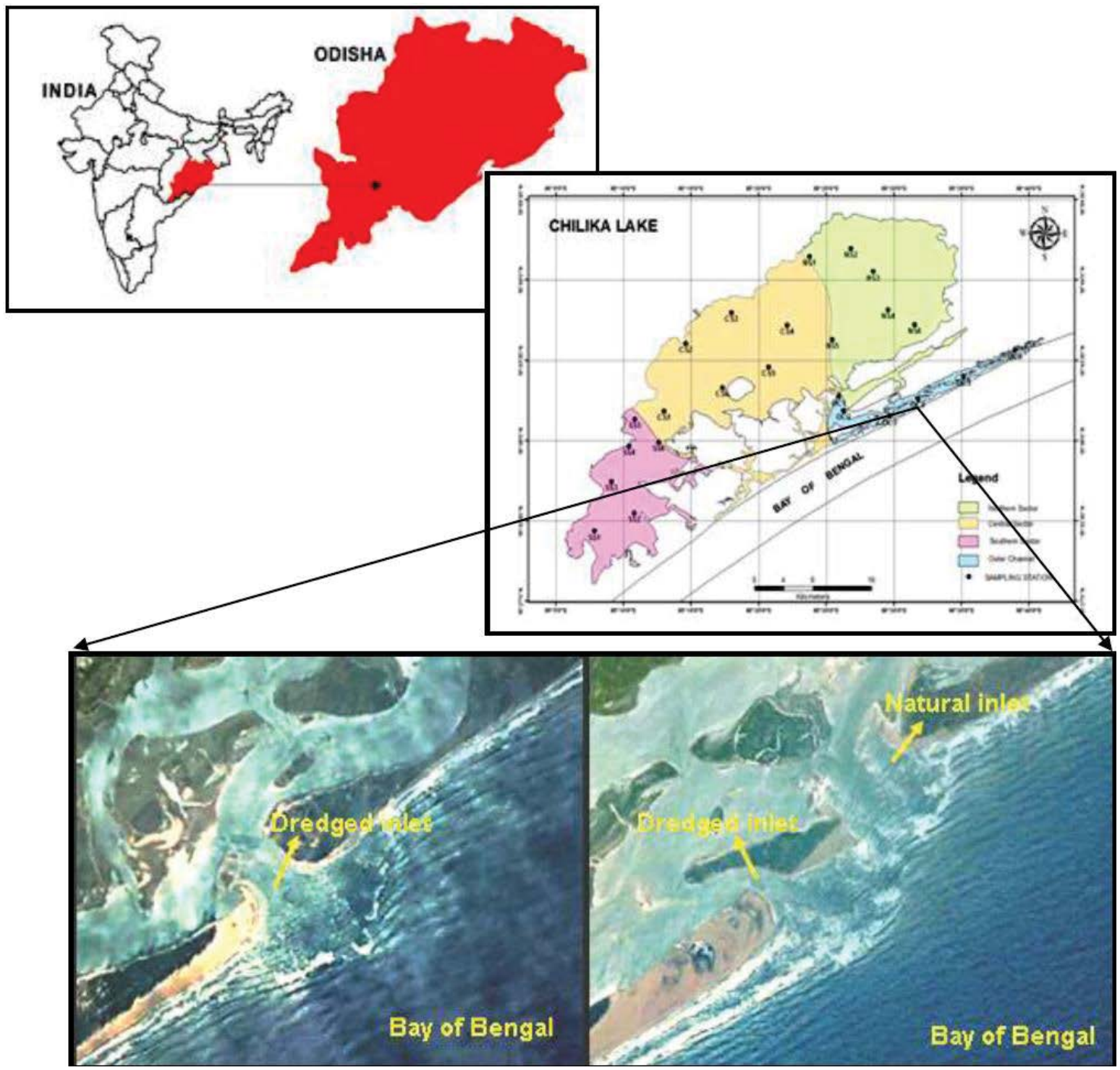

Figure 1: Map of Chilika lake showing sampling points and four ecological sectors and its neighbourhood.

sector having fresh water, central sector having brackish water, southern sector having brackish cum marine water and outer channel as the marine region $[23,24]$. On hydrological front, the lake is connected by three hydrological regimes such as (i) marine incursion from bay Bengal in the east, (ii) Mahanadi distributaries in the northern side and catchment influx from western catchment area, (iii) Palur channel in the south. There is a $16 \mathrm{~km}$ long canal that connects the southern tip of the Chilika lake to the Rushikulya estuary called as the "Palur channel". There are 52 number of river and rivulets bring silt borne fresh water during monsoon which is further out fluxed through the inlets to the Bay of Bengal. During the end period of $20^{\text {th }}$ century, the lagoon inlet was closed due to which the lagoon-sea interaction was disturbed drastically with the sharp declination of salinity. As a consequence, the lagoon had undergone severe ecological degradation with sharp depletion of water quality followed by fisheries output. To revive the lagoon from such destructive condition, a new inlet was dredged at the
"Shipakuda" region of outer channel area during $23^{\text {rd }}$ September 2000. During $1^{\text {st }}$ of August 2008 another mouth was opened at $1 \mathrm{~km}$ northeast of the dredged mouth by natural process [25].

\section{Sample collection and analysis}

In order to get the macrobenthic polychaetes, multiple sediment samples were collected from all the four sectors (Figure 1) of the lake area during 2007 to 2010 by using a Van Veen type of grab sampler having the surface area of $250 \mathrm{~cm}^{2}$. The sediment samples were washed through a sieve of 500 micron. Then the remaining residues over the sieve were collected carefully to plastic containers and preserved in $5 \%$ formaldehyde in sea water containing Rose Bengal solution. Then after, the entire samples were transferred in to the laboratory and washed repeatedly to remove the attached sediment and debris. After that, the polychaetes samples were removed from the group of other macrobenthic fauna. Standard procedure was followed regarding 
Citation: Mahapatro D, Panigrahy RC, Panda S, Mishra RK (2015) An Updated Checklist of Benthic Polychaetes of Asia's Largest Brackish Water Coastal Lagoon -The Chilika Lake. J Coast Zone Manag 18: 406. doi: 10.4172/2473-3350.1000406

Page 3 of 7

polychaetes identification up to species level by using a stereo zoom microscope, followed by available identification keys [26,27].

\section{Results and Discussion}

During the present study a total of forty five species of polychaete taxa belonging to 23 families and 10 orders were reported (Table 1). Spatial distribution of taxa revealed that northern sector had the lowest number having 20 species, while central sector with $27 \mathrm{sp}$. and 25 species from southern sector was reported. But, outer channel area comprised with 39 species. Some of the newly occurred species reported after the opening of new lagoon inlet during the year 2008 were Amphictene auricoma, Spiophanes bombyx, Mediomastus, Pomatoceros caeruleus, Hydroides elegans, Pisione remota, Hesione picta, Eteone picta, Eumida sanguine, Bipalponephtys cornuta etc. Representatives of the families like Capitellidae and Neredidae were widely distributed in the lake sediment such as Nereis reducta, Namalycastis indica, Neanthes chilkensis Capitella capitata and Heteromastus filliformis. Some of the common representatives were those of Sigambra constricta, Nephtys polybranchia, Nepthys oligobranchia, Goniadopsis longicirrata, Myriochele picta, Cossura coasta, Heteromastus filiformis Lumbrineris polydesma

\begin{tabular}{|c|c|c|c|c|c|c|c|c|}
\hline Class & Order & Family & & Genus/species & OC & SS & CS & NS \\
\hline \multirow[t]{46}{*}{ Polychaete } & Phyllodocida & Nereididae & 1 & Nereis reducta Southern, 1921 & + & + & + & + \\
\hline & & & 2 & Neanthes chilkensis Southern, 1921 & + & + & + & + \\
\hline & & & 3 & Neanthes glandicncta Southern, 1921 & + & + & + & + \\
\hline & & & 4 & Namalycastis indica Southern, 1921 & + & + & + & + \\
\hline & & & 5 & Perinereis nigropunctata Horst, 1889 & + & + & + & - \\
\hline & & Nepthtyidae & 6 & Bipalponephtys cornuta Southern, 1921 & + & + & + & + \\
\hline & & & 7 & Nephtys polybranchia Southern, 1921 & + & + & + & + \\
\hline & & & 8 & Nepthys oligobranchia Southern, 1921 & - & + & + & + \\
\hline & & Hesionidae & 9 & Oxydromus fasciatus Grube, 1855 & + & + & + & - \\
\hline & & & 10 & Hesione picta Müller in Grube, 1858 & + & + & + & - \\
\hline & & Pilargidae & 11 & Sigambra constricta Southern, 1921 & + & + & + & + \\
\hline & & Phyllodocidae & 12 & Eulalia viridis Linnaeus, 1767 & + & - & - & - \\
\hline & & & 13 & Eteone picta Quatrefages, 1866 & + & + & - & - \\
\hline & & & 14 & Eumida sanguinea Örsted, 1843 & - & + & - & - \\
\hline & & Goniadidae & 15 & Glycinde oligodon Southern, 1921 & + & + & + & + \\
\hline & & & 16 & Goniadopsis longicirrata Arwindsson, 1899 & + & + & + & + \\
\hline & & Glyceridae & 17 & Glycera alba Southern, 1921 & + & - & - & - \\
\hline & & Sigalionidae & 18 & Pisione remota Southern, 1914 & + & - & - & - \\
\hline & Sabellida & Maldanidae & 19 & Euclymene annandalei, Southern, 1921 & + & + & + & - \\
\hline & & & 20 & Axiothella obockensis Gravier, 1905 & + & + & + & + \\
\hline & & Fabriciidae & 21 & Fabricia spongicola, Southern, 1921 & + & - & + & - \\
\hline & & Oweniidae & 22 & Owenia fusiformis Delle Chiaje, 1844 & + & + & + & - \\
\hline & & & 23 & Myriochele picta Southern, 1921 & + & + & + & + \\
\hline & & Sabellidae & 24 & Chone fauveli Mclntosh, 1916 & + & + & + & + \\
\hline & & Serpulidae & 25 & Pomatoceros caeruleus Fauvel, 1933 & + & - & - & - \\
\hline & & & 26 & Hydroides elegans Haswell, 1883 & + & - & - & - \\
\hline & not assigned & Capitellidae & 27 & Capitella capitata Fabricius, 1780 & + & + & + & + \\
\hline & & & 28 & Notomastus latericus Sars, 1851 & - & + & - & + \\
\hline & & & 29 & Heteromastus filiformis Claparède, 1864 & + & + & + & + \\
\hline & & & 30 & Mediomastus sp., Hartman, 1969 & + & - & + & + \\
\hline & & & 31 & Hetromastus similis Southern, 1921 & - & - & + & + \\
\hline & & & 32 & Pulliella armata Fauvel, 1929 & - & - & - & + \\
\hline & Cossurida & Cossuridae & 33 & Cossura coasta Kitamori, 1960 & + & + & + & - \\
\hline & Eunicida & Onuphidae & 34 & Diopatra neapolitana Delle Chiaje 1844 & + & - & + & - \\
\hline & & Lumbrineridae & 35 & Lumbrineris polydesma Southern, 1921 & + & + & + & + \\
\hline & & Eunicidae & 36 & Lumbriconereis simplex Southern, 1921 & - & + & - & + \\
\hline & Spionida & Spionidae & 37 & Marphysa gravelyi Southern, 1921 & + & + & + & + \\
\hline & & & 38 & Paraprionospio pinnata Ehlers 1901 & + & + & + & + \\
\hline & & & 39 & Minuspio cirrifera Wirén 1883 & + & + & + & + \\
\hline & & & 40 & Spiophanes bombyx Claparède 1870 & + & - & + & - \\
\hline & Scoleisida & Orbiniidae & 41 & Polydora hornelli Willey, 1905 & + & - & - & - \\
\hline & Paraonida & Pilargidae & 42 & Scoloplos marsupialis Southern, 1921 & + & + & + & + \\
\hline & Terebellida & Pectinariidae & 43 & Aricidea lopezi Berkeley and Berkeley, 1956 & + & + & + & + \\
\hline & Eunicida & Onuphidae & 44 & Amphictene auricoma Müller, 1776 & + & - & - & - \\
\hline & & & 45 & Onuphis eremita Audouin and Milne Edwards, 1833 & + & - & - & - \\
\hline & & Total & & 45 & 39 & 25 & 27 & 20 \\
\hline
\end{tabular}

Table 1: Checklist of benthic polychaetes of Chilika lake collected during 2007 to 2010 . 
Citation: Mahapatro D, Panigrahy RC, Panda S, Mishra RK (2015) An Updated Checklist of Benthic Polychaetes of Asia's Largest Brackish Water Coastal Lagoon -The Chilika Lake. J Coast Zone Manag 18: 406. doi: 10.4172/2473-3350.1000406

Page 4 of 7

Minuspio cirrifera, Scoloplos marsupialis, Paraprionospio pinnata, Capitella capitata (Figure 2). All the representatives of Capitellidae observed during the present study were deposit feeders. But, Nereididae representatives were belonged to suspension feeders. Available information revealed that the northern sector contained with soft mud enriched with organic matter. Southern sector, Nalabana bird Is., and outer channel region is comprised with sandy sediment [25]. Presence of 39 polychaete species in outer channel region in contrast of 20 species from northern sector revealed that most of the observed taxa favoured to live in sandy sediment than the soft mud. Similar observations were made earlier in different parts [21,28,29]. This is because of the clogging in the feeding apparatus of the filter feeders by the fine clay sediment. In fact, filter feeders feed upon the suspended planktonic matter present in the water column. But deposit feeders conversely

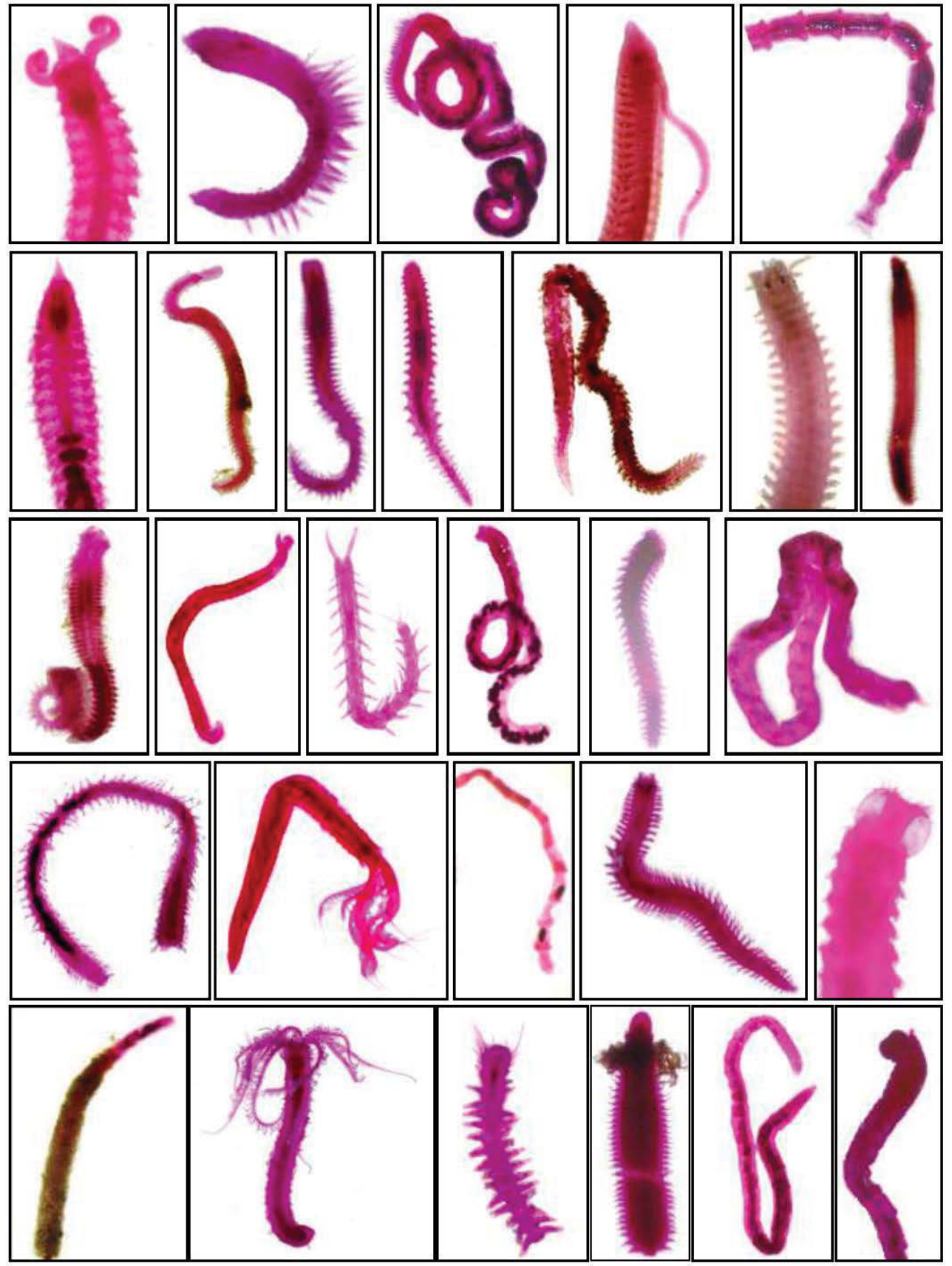

Figure 2: Benthic polychaetes of Chilika lake. From left to right Polydora hornelii, Prionospio pinnata, Minuspio cirrifera, Cossura coasta, Axiothella obockensis, Aricidia sp., Glycinde oligodon, Nepthys oligobranchia, Nepthys cornuta, Nemalycastis indica, Perinereis nigropunctata,Drilonereis, S. constricta, Goniada, Pissione, Heteromastus similis, Ophiodrumus, Mediomastus, Eteone, Chon fauveli, Euclyemene annandeli, Nereis reducta, Marphyssa falax, Myriochele picta, Fabricia spongicola, Hesione, Lumbrinereis polydesma, Capitella capitata, Heteromastus filliformis. 
Citation: Mahapatro D, Panigrahy RC, Panda S, Mishra RK (2015) An Updated Checklist of Benthic Polychaetes of Asia's Largest Brackish Water Coastal Lagoon -The Chilika Lake. J Coast Zone Manag 18: 406. doi: 10.4172/2473-3350.1000406

Page 5 of 7

\begin{tabular}{|c|c|c|c|}
\hline Genus/species & Present study & ZSI 1995 & Southern 1921 \\
\hline Nereis reducta Southern, 1921 & + & + & + \\
\hline Neanthes chilkensis Southern, 1921 & + & + & + \\
\hline Neanthes glandicncta Southern, 1921 & + & + & - \\
\hline Namalycastis indica Southern, 1921 & + & + & - \\
\hline Perinereis nigropunctata Horst 1889 & + & + & + \\
\hline Bipalponephtys cornuta Southern, 1921 & + & - & - \\
\hline Nephtys polybranchia Southern, 1921 & + & + & + \\
\hline Nepthys oligobranchia Southern, 1921 & + & + & + \\
\hline Oxydromus fasciatus Grube, 1855 & + & - & - \\
\hline Hesione picta Müller in Grube, 1858 & + & + & - \\
\hline Sigambra constricta Southern, 1921 & + & + & - \\
\hline Eulalia viridis Linnaeus, 1767 & + & - & - \\
\hline Eteone picta Quatrefages, 1866 & + & + & + \\
\hline Eumida sanguinea Örsted, 1843 & + & - & - \\
\hline Glycinde oligodon Southern, 1921 & + & - & + \\
\hline Goniadopsis longicirrata Arwindsson, 1899 & + & + & - \\
\hline Glycera alba Southern, 1921 & + & - & Tylonereis fauveli, \\
\hline Pisione remota Southern, 1914 & + & - & Sternaspis costata \\
\hline Euclymene annandalei, Southern, 1921 & + & - & + \\
\hline Axiothella obockensis Gravier, 1905 & + & - & Laonome indica \\
\hline Fabricia spongicola, Southern, 1921 & + & - & + \\
\hline Owenia fusiformis Delle Chiaje, 1844 & + & + & - \\
\hline Myriochele picta Southern, 1921 & + & + & + \\
\hline Chone fauveli Mclntosh, 1916 & + & - & - \\
\hline Pomatoceros caeruleus Fauvel, 1933 & + & + & - \\
\hline Hydroides elegans Haswell, 1883 & + & + & - \\
\hline Capitella capitata Fabricius, 1780 & + & + & - \\
\hline Notomastus latericus Sars, 1851 & + & + & - \\
\hline Heteromastus filiformis Claparède, 1864 & + & - & - \\
\hline Mediomastus sp., Hartman, 1969 & + & - & - \\
\hline Hetromastus similis Southern, 1921 & + & - & + \\
\hline Pulliella armata Fauvel 1929 & + & - & - \\
\hline Cossura coasta Kitamori 1960 & + & - & - \\
\hline Diopatra neapolitana Delle Chiaje 1844 & + & + & + \\
\hline Lumbrineris polydesma Southern, 1921 & + & + & + \\
\hline Lumbriconereis simplex Southern, 1921 & + & + & + \\
\hline Marphysa gravelyi Southern, 1921 & + & + & + \\
\hline Paraprionospio pinnata Ehlers 1901 & + & - & - \\
\hline Minuspio cirrifera Wirén 1883 & + & + & - \\
\hline Spiophanes bombyx Claparède 1870 & + & + & - \\
\hline Polydora hornelli Willey 1905 & + & - & + \\
\hline Scoloplos marsupialis Southern, 1921 & + & - & + \\
\hline Aricidea lopezi Berkeley \& Berkeley 1956 & + & - & - \\
\hline Amphictene auricoma Müller 1776 & + & - & - \\
\hline Onuphis eremita Audouin \& Milne Edwards, 1833 & + & - & - \\
\hline
\end{tabular}

Table 2: Comparison of species composition of benthic polychaetes with previous studies.

seen in muddy sediment and feed up on decomposed organic matter $[28,29]$. Thus sediment composition played a significant role in the distribution of benthic animal. This is well corroborated with findings of Sanders [30] who proposed regarding animal-sediment relationship. Similar observations were also documented by Palacin et al. [31] while working on Mediterranean Bay. Chilika lake has large expansion of sea grass meadow mostly at southern sector, Nalabana bird Is. and outer channel area. It was appeared as the best habitat for colonising the benthic polychaets. The present study documented some of that genus such as Chone, Axiothella, Aricidea, Scoloplos, Paraprionospio,
Polydora, Clymenella, Fabricia, Capitella, Mediomastus, Heteromastus, Notomastus, Sigambra, Glycinde, Goniada, Marphysa, Lumbrineris, Amphictene. Similar observations were made in the region of Southeast Brazil [32].

The observations made in the present study regarding the species composition of benthic polychaete can be comparable with earlier findings from this ecosystem. In the Table 2 comparison was made with the findings of ZSI [33] and Southern [22] reported 31 and 20 number respectively. However, $74 \%$ of polychaetes from 1995 data set and $85 \%$ of the polychaetes from 1921 data set was found almost similar with 
Citation: Mahapatro D, Panigrahy RC, Panda S, Mishra RK (2015) An Updated Checklist of Benthic Polychaetes of Asia's Largest Brackish Water Coastal Lagoon -The Chilika Lake. J Coast Zone Manag 18: 406. doi: 10.4172/2473-3350.1000406

the present study. It is noteworthy to mention here that during 1995 most of the brackish water species were prevailed in the lake ecosystem. The average salinity of the lake at that period was 5 ppt [33]. But, polychaetes species observed by Sewell and Annandale [34,35] were of typical marine forms and high salinity was also reported. Hence, it is established that higher salinity favours more marine forms rather than the brackish water species. This is in congruence with the findings of Mahapatro et al. [20].

Species composition of the present study virtually compared with other ecosystem of India. Studies made in south east coast of India by Musale and Desai [3] from the polluted regions of Mumbai harbour reported 63 polychaeta species. Similarly, Sukumaran and Saraladevi [15] reported 84 polychaete species whereas 71 polychaeta species were documented from polluted estuarine system of Zuari estuary reported by Sivadas et al. [17]. Subsequently, Mandal and Harkantra [19] found 31 polychaete species while working on Mumbai port. But, recently Mahapatro et al. [20] reported 39 polychaetes species along the outer channel area of Chilika lake. Interestingly, the species composition of benthic polychaete appeared in the different coastal ecosystems of India was apparently same with species compositions documented during this study.

\section{Pollution indicator species}

Many families of polychaetes were well reported as pollution indicators. However considering any species as indicator of pollution, there are certain criterions as described by Gaufin and Tarzwell [36] such as (i) high numerical density, (ii) few species in the fauna, (iii) feeding habit must be of scavenger type and (iv) tolerance or adaptation for low dissolved oxygen. Again, its presence should be negligible in high diversity rich areas or unpolluted regions. Under such condition certain polychaete taxa fall on this category. Most of them are belonging to the family Spionidae, Capitellidae, Pilargidae etc. Dominant representatives were those of Capitella capitata, Minuspio cirrifera and S. constricta [15]. Polychaetes like Capitella capitata, Minuspio cirrifera can able to tolerate the hypoxic conditions [6,15]. According to Musale and Desai [3], the deposit feeders Capitella and P. pinnata were found in the sediment which is enriched with organic sewage. Similarly, Martin et al. [18] observed Minuspio cirrifera and C. capitata as a dominant species in organically enriched regions of Cochin backwater. In Chilika lake, such indicator species were observed in the northern and central sector region. These regions were much influenced by the organic matter because of the huge decomposition of macrophytes [23].

\section{Conclusion}

In the present study, the obtained polychaetes taxa were similar with other coastal ecosystems of India. Preponderance of 45 polychaete species from the lake sediment exhibited healthy condition of the study area. But dominance of Capitella sp., and Minuspio sp., in the northern sector of the lake indicated the occurrence of organic enrichment. However, many of the species occured for the first time in this system were belonging to marine habitat. This might be corroborated as the opening of new lagoon inlet. Since, very less information is gathered regarding the benthic polychaete taxa of the Chilika lake. Thus providing any of the conclusive remark is found difficult. The present findings may be considered as the baseline information for further investigation.

\section{Acknowledgement}

The authors are thankful to H.O.D. P.G. Department of Marine Sciences,
Berhampur University and Chilika Development Authority, Bhubaneswar, Odisha, India. Thanks are also given to A.K. Mahapatro of Estuarine Biological station Gopalpur on sea, ZSI for his kind suggestion. One of the authors also thanks to the Director, NCAOR for his continuous support for scientific publication.

\section{References}

1. Alongi DM (1990) The ecology of tropical soft-bottom benthic ecosystems, Oceanogr. Mar Biol Annu. Rev 28: 381-496.

2. Gaonkar UK, Sivadas SK, Ingole BS (2013) Effect of tropical rainfall in structuring the macrobenthic community of Mandovi Estuary, west coast of India. J Mar Biol Assoc 93: 1727-1738.

3. Musale AS, Desai DV (2011) Distribution and abundance of macrobenthic polychaetes along the south Indian coast Environmental Monitoring and Assessment Springer 178; 423-436.

4. Dean HK (2008) The use of polychaetes (Annelida) as indicator species of marine pollution: a review. Int J Trop Biol. 56: 11-38.

5. Surugiu V (2005) The use of poychaetes as indicators of eutrophication and organic enrichment of coastal waters: a study case - Romanian Black Sea Coast. Analete Stiintifice ale Universitatii "Al. I. Cusa" lasi, s Biologie animal. 51: 55-62.

6. Pearson TH, Rosenberg R (1978) Macrobenthic succession in relation to organic enrichment and pollution of the marine environment Oceanogr Mar Biol: Ann Rev. 16: 229-311.

7. Warwick RM, Ruswahyuni (1987) Comparative study of the structure of some tropical and temperate marine soft bottom macrobenthic communities, Mar Bio. 95: 641-649.

8. Elias R, Palacios JR, Rivero MS, Vallarino EA (2005) Short term responses to sewage discharge and storms of subtidal sand-bottom macrozoobenthic assemblages off Mar del Plata City, Argentina (SW Atlantic), J Sea Res. 53: 231-242.

9. Shou L, Huang Y, Zeng J, Gao A, Liao Y, et al. (2009) Seasonal changes of macrobenthos distribution and diversity in Zhoushan sea area. Aquatic Ecosystem Health and Management. 12: 110-115.

10.Parulekar AH, Harkantra SN, Ansari ZA (1982) Benthic production and the assessment of demersal fishery resources of the Indian sea. Indian Journal of Marine Sciences. 11: 107-114.

11. Hodson RG, Hackman JO and Bennett CR (1981) Food habits of young spots in nursery areas of the Cape FearRiver Estuary, North Carolina. Transactions of the American Fisheries Society. 110: 495501.

12.Pillai NGK (2001) On some benthic polychaetes from Cochin Estuary J mar Biol Ass India. 43: 120 - 135.

13.Sarkar SK, Bhattacharya AK, Giri S, Bhattacharya B Sarkar D, Nayak DC, et al. (2005) Spatiotemporal variation in benthic polychaetes (Annelida) and relationships with environmental variables in a tropical estuary. Wetlands Ecology and Management 13: 55-67.

14.Raut D, Ganesh T, Murty NVVS, Raman AV (2005) Macrobenthos of Kakinada Bay in the Godavari delta, east coast of India: Comparing decadal changes. Estuarine, Coastal and Shelf Science, 62: 609-620.

15.Sukumaran S, Saraladevi K (2009) Polychaete diversity and its relevance in the rapid environmental assessment of Mumbai port, Curr Sci. 97: 1439-1444.

16.Kundu S, Mondal N, Lyla PS, Ajmal Khan S (2009) Biodiversity and seasonal variation of macro-benthic infaunal community in the inshore waters of Parangipettai Coast Environ Monit Assess. 163: 67-79.

17.Sivadas S, Ingole B, Nanjkar M (2010) Benthic polychaete as good indicators of anthropogenic impact. Indian J Mar Sci 39; 201-211. 
Citation: Mahapatro D, Panigrahy RC, Panda S, Mishra RK (2015) An Updated Checklist of Benthic Polychaetes of Asia's Largest Brackish Water Coastal Lagoon -The Chilika Lake. J Coast Zone Manag 18: 406. doi: 10.4172/2473-3350.1000406

Page 7 of 7

18. Martin GD, Nisha PA, Balachandran KK, Madhu NV, Nair M, et al. (2011) Eutrophication induced changes in benthic community structure of a flow-restricted tropical estuary (Cochin backwaters), India. Environmental Monitoringand Assessment, 176: 427-438.

19.Mandal S and Harkantra SN (2013) Changes in the soft bottom macrobenthic diversity and community structure from the ports of Mumbai, India. Environ Monit Assess 185: 653-672.

20.Mahapatro D, Panigrahy RC, Panda S, Mishra RK (2015) Checklist of intertidal benthic macrofauna of a brackish water coastal lagoon on east coast of India: The Chilika lake. Int Jour of Mar Sc 5: 1-13

21. Harkantra SN, Parulekar AH (1985) Community structure of sanddwelling macrofauna of an estuarine beach in Goa, India Mar Ecol Prog Ser 30: 291-294.

22.Southern R (1921) Polychaets of Chilika Lake and also fresh wand brackish waters in other poarts of India. Mem Ind Mus. 5: 563-655.

23. Mahapatro D, Mishra RK, Samal RN, Patanaik AK (2012) Study of Macrobenthos in Relation to Eutrophication at Chilika Lagoon, East Coast of India Mar Sci 2: 139-148.

24.Panigrahy RC (2000) The Chilka lake-a sensitive coastal ecosystem of Orissa, east coast of India. J Indian Ocean Stud 7: 222-242.

25.Panda S, Bhatta, KS, Rath KC, Misra CR, Samal, RN (2008) The Atlas of Chilika, (Chilika Development Authority, Bhubaneswar, India) 133.

26.Fauvel P (1953) The fauna of India- Annelida, polychaeta including Pakistan, Cylon, Burma and Malaya (The Indian Press Allahabad),
$1-507$.

27.Gosner KL (1971) Guide to Identification of Marine and Estuarine Invertebrates, Wiley Interscience:New York, 300.

28. Harkantra SN, Rodrigues CL, Parulekar AH (1982) Macrobenthos of the shelf off Northeastern bay of Bengal. Indian J Mar Sci 11:115-121.

29.Jayaraj KA, Jayalakshmi KV, Saraladevi K (2007) Influence of environmental properties on macrobenthos in the northwest Indian shelf. Env. Mon. Asses 127; 459-475.

30.Sanders HL (1958) Benthic studies in Buzzards Bay. AnimalSediment relationships. Limnology and Oceanography 3: 245-258.

31.Palacin C, Martin D, Gili JM (1991) Features of spatial distribution of benthic infauna in a Mediterranean shallow water Bay. Marine Biology 110: 315-321.

32. Omena E, Creed JC (2004) Polychaete Fauna of Seagrass Beds (Halodule wrightii Ascherson) along the Coast of Rio de Janeiro (Southeast Brazil). Marine Ecology 25: 273-288.

33.ZSI (1995) Fauna of Chilika Lake, (Ed. Zoological Survey of India, Calcutta) 672.

34.Sewell RBS and Annandale N (1922) Fauna of Chilka Lake: The hydrography and invertebrate fauna of Rhambha Bay in an abnormal year. Mem Indian Mus 5: 700-702.

35.Levin LA (2000) Polychaetes as environmental indicators: response to low oxygen and organic enrichment. Bull Mar Sci 67: 668.

36. Gaufin AR and Tarzwell CM (1952) Aquatic invertebrates as indicators of stream pollution. Public Health Report 67: 57-64. 